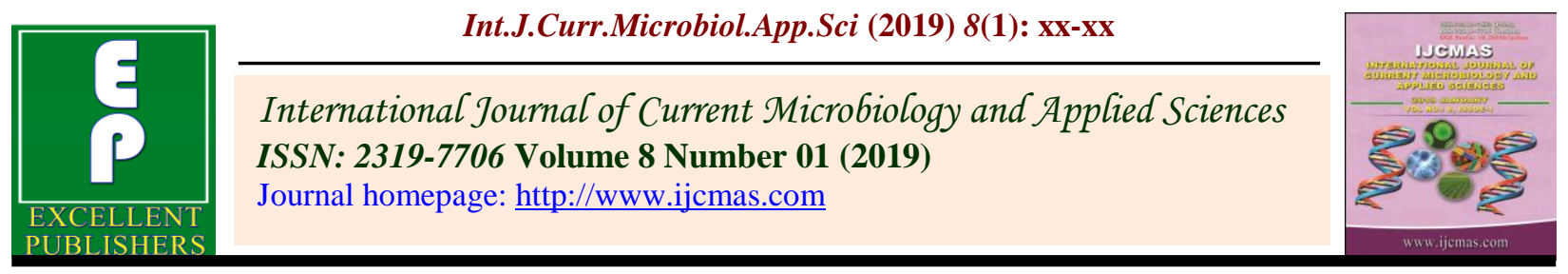

Original Research Article

https://doi.org/10.20546/ijcmas.2019.801.043

\title{
Soil Fertility Status of Some Villages in Khordha and Bhubaneswar Block of Khordha District under North Eastern Ghat Agro Climatic Zone of Odisha, India
}

\author{
Nibedita Swain ${ }^{1}$, Antaryami Mishra², Subhashis Saren ${ }^{2}$, Prava Kiran Dash ${ }^{2}$, \\ Manoranjan Digal ${ }^{3}$ and Bbhuti Bhusan Mishra ${ }^{1}$ \\ ${ }^{1}$ Department of Botany, College of Basic Science and Humanities, OUAT \\ ${ }^{2}$ Department of Soil Science and Agricultural Chemistry, College of Agriculture, OUAT \\ ${ }^{3}$ Department of Chemistry, College of Basic Science and Humanities, Odisha University of \\ Agriculture and Technology, Bhubaneswar, Odisha-751003, India \\ *Corresponding author
}

\section{A B S T R A C T}

\begin{tabular}{|l|}
\hline Ke y w or d s \\
Soil fertility, Agro \\
Climatic Zone, \\
Khordha, Odisha \\
\hline Article Info \\
\hline $\begin{array}{l}\text { Accepted: } \\
\text { 04 December } 2018 \\
\text { Available Online: } \\
\text { 10 January 2019 }\end{array}$ \\
\hline
\end{tabular}

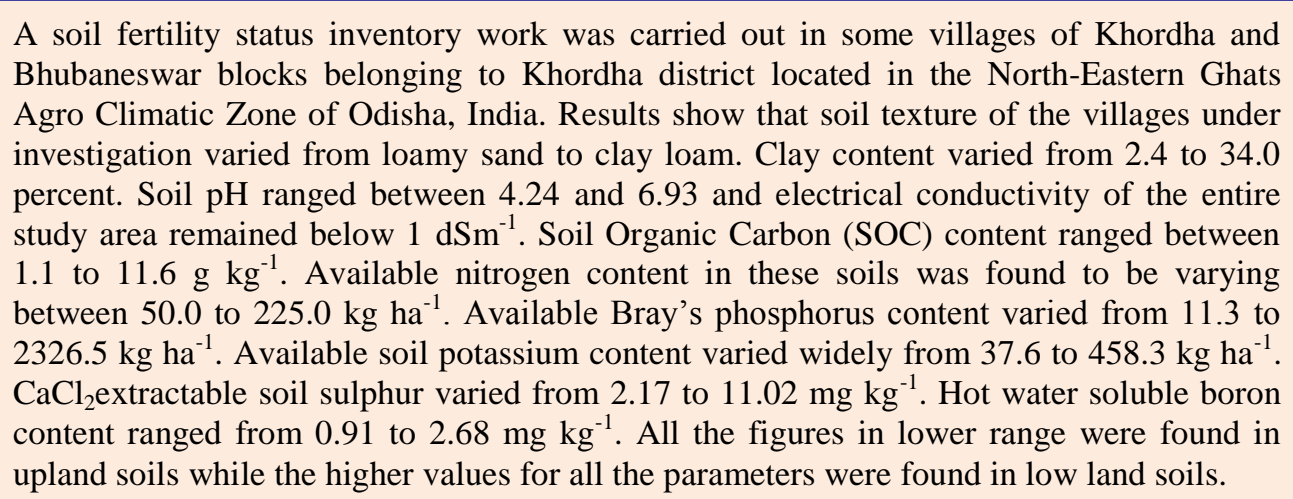

\section{Introduction}

Khordha and Bhubaneswar blocks belong to Khordha district which comes under North Eastern Ghat Agro Climatic Zone of Odisha (Nanda et al., 2008). As per modern system of soil classification "Soil Taxonomy" the soils of Khordha district are classified under the Alfisols, Inceptisols and Entisols (Sahu and Mishra, 2005). Proper application of fertilizers helps in maximizing marketable yields whereas excessive use may be harmful to the environment. Hence, evaluation of soil fertility status of different land types of an area is of primary importance for a balanced application of fertilizers and manures as well as to increase the productivity per unit of cultivable land to cater the growing need of cereals, pulses, oil seeds, fruits and vegetables for the growing population. In the present 
scenario, soil testing is now considered as an important tool for the recommendation of fertilizer doses for various crops. Again, GPS (Global Positioning System) based soil fertility evaluation not only gives ideas about fertility status of the soil but also helps in monitoring the soil health from time to time.

Focusing on these concepts, four villages of Khordha and Bhubaneswar blocks of Khordha district namely Kuaput, Haladia, Kumvadei and Khatuapadawere selected for studying the GPS based soil fertility status in order to identify the major soil fertility related crop production constraints. Although soil fertility status and maps have been prepared for different blocks of Odisha, but no such intensive work had been done for these villages of the district which have vast areas of agricultural lands. Therefore an attempt was made in the present investigation to prepare soil fertility status of four selected villages of the district. Soils were analysed for some of the basic soil physical and chemical properties which includes mechanical analysis (soil texture), soil pH, EC and SOC. Soil fertility status is evaluated focusing on the most important nutrients for the plant such as nitrogen, phosphorus, potassium, sulphur and boron. This study will help in finding out soil fertility related crop production constraints along with suggesting remedial measures for higher crop production.

\section{Materials and Methods}

\section{Experimental site}

Out of the four villages under investigation, two villages namely Kuaput and Haladia, are situated in Khordha block (situated at a distance of $15 \mathrm{kms}$ from Khordha - Banki road) and the rest two villages namely Kumvadei and Khatuapada are situated in Bhubaneswar block of Khordha district (situated on the foot hill the famous Dhauligiri hill on both sides of the historic river Daya). Both Dhauligiri hill and Dayariver are associated with Ashoka-the Great because of the Kalinga war.

The mean annual rainfall of the study area is $1597 \mathrm{~mm}$. The mean maximum summer temperature is $37^{\circ} \mathrm{C}$ and the mean minimum winter temperature is $10.4^{0} \mathrm{C}$. The climate is hot, moist and sub-humid. The soils of this Agro Climatic zone are mostly red loam, brown forest soils (Haplustalfs, Rhodustalfs, Ustochrepts, Ustorthents).

\section{Soil sampling and analysis}

The landform of the study area was determined through traversing the area and elevations above MSL of different points were recorded using GPS instrument (Garmin make; model: 76MAPCSx). Total 40 numbers of composite surface $(0-15 \mathrm{~cm})$ soil samples were collected from the study area which includes 10 samples from each village from different land types such as upland, medium land and low land. Composite soil samples were collected along with latitude and longitude of the plots with the help of GPS instrument. Soils were analysed for its textural class by Bouyoucos Hydrometer method (Bouyoucos, 1962), pH(1:2) (Jackson, 1973), EC(1:2) (Jackson, 1973), organic carbon (Walkley and Black, 1934) as described by Page et al.,(1982), available nitrogen (Subbiah and Asija, 1956), phosphorus (Bray and Kurtz, 1945), potassium (Hanway and Heidel, 1952), sulphur (Chesnin and Yien, 1950), and hot water extractable boron (John et al., 1975).

\section{Results and Discussion}

\section{Soil texture}

The sand, silt and clay content in the soils of Kuaput village were found to vary in between 78.4 to $92.4,1.6$ to 5.2 and 5.3 to 17.4 percent 
respectively; that of Haladia village varied between 53.4 to $65.8,7.6$ to 14.2 and 23.6 to 34.0 percent respectively; that of Kumvadei varied between 79.0 to $95.4,2.2$ to 10.6 and 2.4 to 11.4 percent respectively; that of Khatuapada village varied between 75.4 to $93.4,2.0$ to 9.2 and 4.4 to 15.4 percent respectively (Table 1). From the Table 1, it is clear that the average clay content increased from upland to low land in all the four villages, which could be attributed to washing away of clay particles from upland and medium land (along with runoff water during heavy rain fall and their subsequent deposition in the low land. Similar findings have also been observed by Nayak (2014) ${ }^{[17]}$, Mishra et al., (2014), Digal et al., (2018) ${ }^{[12]}$ and Dash et al., $(2018)^{[6]}$.

\section{Soil reaction}

Soil $\mathrm{pH}(1: 2)$ of surface soil samples of Kuaput village were found to vary in between 4.6 to 6.1 with a mean value of 5.38; that of soils of Haladia village varied between 5.7 to 6.9 with a mean value of 6.57; that of Kumvadei varied between 4.2 to 6.0 with a mean value of 5.19; that of soils of Khatuapada village varied between 4.9 to 6.1 with a mean value of 5.35 (Table 2). The data showed a gradual increase in soil $\mathrm{pH}$ value from upland towards low land, which could be attributed to the removal of basic cations with runoff water from upland and medium land during intensive rainfall and their subsequent deposition in the low land. Hence, the soil acidity appears to be a major crop production constraint in the study area. Similar findings have also been reported earlier by Priyadarshini et al., (2017) andDash et al., (2018).

\section{Electrical conductivity}

Electrical Conductivity (1:2) of surface soil samples of the entire study area was found to be less than $1 \mathrm{dS} \mathrm{m}^{-1}$ (Table 2). Hence, all the soils under the study area are safe for all types of crop production with respect to the soluble salt content.

\section{Organic carbon}

Soil Organic Carbon (SOC) of surface soil samples of Kuaput village were found to vary in between 2.3 to $7.6 \mathrm{~g} \mathrm{~kg}^{-1}$ with a mean value of $4.7 \mathrm{~g} \mathrm{~kg}^{-1}$; that of Haladia village varied between 4.3 to $9.6 \mathrm{~g} \mathrm{~kg}^{-1}$ with a mean value of $7.0 \mathrm{~g} \mathrm{~kg}^{-1}$; that of Kumvadei varied between 1.1 to $11.6 \mathrm{~g} \mathrm{~kg}^{-1}$ with a mean value of $6.7 \mathrm{~g}$ $\mathrm{kg}^{-1}$; that of Khatuapada village varied between 1.2 to $10.7 \mathrm{~g} \mathrm{~kg}^{-1}$ with a mean value of $7.1 \mathrm{~g} \mathrm{~kg}^{-1}$ (Table 2). The results clearly showed a gradual increase in average SOC from upland towards low land surface soil samples which could be attributed to higher cropping intensity aided with more crop residue incorporation in the same. Again, due to higher water table, the oxidation of organic matter is slower in low land areas than that of upland areas. In the entire study area organic carbon status was found to be low to high which enables the soil for growing a wide range of crops. Similar findings have also been reported by Mishra (2013), Digal et al., (2018).

\section{Available nitrogen}

Available soil nitrogen content of surface soil samples of Kuaput village were found to vary in between 50 to $188 \mathrm{~kg} \mathrm{ha}^{-1}$ with a mean value of $123.7 \mathrm{~kg} \mathrm{ha}^{-1}$; that of soils of Haladia village varied between 63 to $138 \mathrm{~kg} \mathrm{ha}^{-1}$ with a mean value of $106.2 \mathrm{~kg} \mathrm{ha}^{-1}$; that of soils of Kumvadei varied between 50 to $225 \mathrm{~kg} \mathrm{ha}^{-1}$ with a mean value of $131.2 \mathrm{~kg} \mathrm{ha}^{-1}$; that of soils of Khatuapada village varied between 50 to $225 \mathrm{~kg} \mathrm{ha}^{-1}$ with a mean value of $118.8 \mathrm{~kg}$ $\mathrm{ha}^{-1}$ (Table 3). The results clearly showed a gradual increase in average $\mathrm{N}$ content from upland to low land which could be attributed to the increased SOC in the low land than that 
of upland and medium land (as $\mathrm{N}$ is released from the soil organic matter by the activity of microorganisms). Available $\mathrm{N}$ was found to be positively correlated with organic carbon $\left(\mathrm{r}=0.76^{* *}\right)$ (Table 4). In the entire study area available soil nitrogen content varied between low to medium. Similar results were reported by Behera et al., (2016)

\section{Available phosphorus}

Available soil phosphorus content of Kuaput village were found to vary in between 13 to 36 $\mathrm{kg} \mathrm{ha}^{-1}$ with a mean value of $22 \mathrm{~kg} \mathrm{ha}^{-1}$; that of Haladia village varied between 11 to $28 \mathrm{~kg}$ $\mathrm{ha}^{-1}$ with a mean value of $16.7 \mathrm{~kg} \mathrm{ha}^{-1}$; that of Kumvadei varied between 14 to $52 \mathrm{~kg} \mathrm{ha}^{-1}$ with a mean value of $28.4 \mathrm{~kg} \mathrm{ha}^{-1}$; that of
Khatuapada village varied between 18 to 90 $\mathrm{kg} \mathrm{ha}^{-1}$ with a mean value of $50.0 \mathrm{~kg} \mathrm{ha}^{-1}$ (Table 3).

The results clearly showed a gradual increase in average $\mathrm{P}$ content from upland to low land which could be attributed to the increased SOC in the low land than that of upland and medium land (as organic fractions of available phosphorus is mobilized to plant available form by the activity of microorganisms). Available $\mathrm{P}$ was found to be positively correlated with organic carbon $\left(\mathrm{r}=0.54^{*}\right)$ (Table 4). In the entire study area available phosphorus was found within the range of low to high. Similar trends of available $\mathrm{P}$ were also observed by Barik et al., (2017).

Table.1 Mechanical composition of soils of the study area

\begin{tabular}{|c|c|c|c|c|c|c|c|}
\hline \multirow{2}{*}{$\begin{array}{l}\text { Name of } \\
\text { Village }\end{array}$} & \multirow{2}{*}{$\begin{array}{l}\text { Land } \\
\text { Type }\end{array}$} & \multicolumn{2}{|c|}{$\%$ Sand } & \multicolumn{2}{|c|}{$\%$ Silt } & \multicolumn{2}{|c|}{ \% Clay } \\
\hline & & Range & Mean & Range & Mean & Range & Mean \\
\hline \multirow[t]{3}{*}{ Kuaput } & Upland & $91.4-92.4$ & 92.0 & $2.2-3.2$ & 2.5 & $5.3-5.6$ & 4.8 \\
\hline & $\begin{array}{l}\text { Medium } \\
\text { Land }\end{array}$ & $88.2-90.4$ & 88.9 & $2.2-5.2$ & 4.2 & $6.6-7.4$ & 6.9 \\
\hline & $\begin{array}{l}\text { Low } \\
\text { Land }\end{array}$ & $78.4-87.2$ & 83.4 & $1.6-4.2$ & 3.3 & $8.6-17.4$ & 13.2 \\
\hline \multirow[t]{3}{*}{ Haladia } & Upland & $56.8-65.8$ & 60.8 & $10.6-14.2$ & 12.1 & $23.6-29.0$ & 27.0 \\
\hline & $\begin{array}{l}\text { Medium } \\
\text { Land }\end{array}$ & $58.8-60.8$ & 59.4 & $9.6-11.6$ & 10.8 & $29.4-30.0$ & 29.6 \\
\hline & $\begin{array}{l}\text { Low } \\
\text { Land }\end{array}$ & $53.4-56.8$ & 55.4 & $7.6-12.2$ & 10.3 & $31.0-34.0$ & 33.0 \\
\hline \multirow[t]{3}{*}{ Kumvadei } & Upland & $93.4-95.4$ & 94.4 & $2.2-3.2$ & 2.5 & $2.4-3.4$ & 3.0 \\
\hline & $\begin{array}{l}\text { Medium } \\
\text { Land }\end{array}$ & 89.4-91.4 & 90.2 & $3.2-5.6$ & 4.7 & $3.4-7.4$ & 5.0 \\
\hline & $\begin{array}{l}\text { Low } \\
\text { Land }\end{array}$ & $79.0-87.0$ & 83.1 & $5.6-10.6$ & 7.5 & 7.4-11.4 & 9.4 \\
\hline \multirow[t]{3}{*}{ Khatuapada } & Upland & 88.4-93.4 & 91.7 & $2.0-5.2$ & 3.0 & $4.4-6.4$ & 5.0 \\
\hline & $\begin{array}{l}\text { Medium } \\
\text { Land }\end{array}$ & $89.2-93.2$ & 90.6 & $3.0-3.2$ & 3.0 & $6.8-7.8$ & 7.3 \\
\hline & $\begin{array}{l}\text { Low } \\
\text { Land }\end{array}$ & $75.4-87.2$ & 82.0 & $3.0-9.2$ & 5.9 & $11.4-15.4$ & 13.6 \\
\hline
\end{tabular}


Table.2 Chemical properties of soils of the study area

\begin{tabular}{|c|c|c|c|c|c|c|c|}
\hline \multirow[t]{2}{*}{$\begin{array}{c}\text { Name of } \\
\text { Village }\end{array}$} & \multirow[t]{2}{*}{ Land Type } & \multicolumn{2}{|c|}{ pH (1:2) } & \multicolumn{2}{|c|}{$\begin{array}{l}\operatorname{EC~}(1: 2) \\
\left(\mathrm{dS} \mathrm{m^{-1 }}\right)\end{array}$} & \multicolumn{2}{|c|}{$\begin{array}{c}\mathrm{OC} \\
\left(\mathrm{g} \mathrm{kg}^{-1}\right)\end{array}$} \\
\hline & & Range & Mean & Range & Mean & Range & Mean \\
\hline \multirow[t]{3}{*}{ Kuaput } & Upland & $4.6-5.1$ & 4.8 & $0.05-0.06$ & 0.06 & $2.3-3.2$ & 2.7 \\
\hline & $\begin{array}{l}\text { Medium } \\
\text { Land }\end{array}$ & $5.1-5.5$ & 5.2 & $0.06-0.07$ & 0.06 & $4.0-4.5$ & 4.2 \\
\hline & Low Land & $5.6-6.1$ & 5.8 & $0.07-0.12$ & 0.09 & 5.4-7.6 & 6.4 \\
\hline \multirow{3}{*}{ Haladia } & Upland & $5.7-6.5$ & 6.1 & $0.05-0.11$ & 0.05 & $4.3-5.2$ & 4.9 \\
\hline & $\begin{array}{l}\text { Medium } \\
\text { Land }\end{array}$ & $6.5-6.7$ & 6.6 & $0.11-0.13$ & 0.12 & $6.0-6.9$ & 6.3 \\
\hline & Low Land & $6.7-6.9$ & 6.8 & $0.13-0.19$ & 0.15 & 7.6-9.6 & 9.0 \\
\hline \multirow[t]{3}{*}{ Kumvadei } & Upland & $4.2-4.9$ & 5.6 & $0.01-0.06$ & 0.03 & $1.1-3.4$ & 1.4 \\
\hline & $\begin{array}{l}\text { Medium } \\
\text { Land }\end{array}$ & $5.0-5.1$ & 5.1 & $0.08-0.20$ & 0.13 & $5.2-9.7$ & 6.9 \\
\hline & Low Land & $5.4-6.0$ & 5.7 & $0.3-0.8$ & 0.53 & $9.8-11.6$ & 10.5 \\
\hline \multirow[t]{3}{*}{ Khatuapada } & Upland & $4.9-5.0$ & 5.0 & $0.01-0.02$ & 0.01 & $1.2-6.0$ & 4.4 \\
\hline & $\begin{array}{l}\text { Medium } \\
\text { Land }\end{array}$ & $5.1-5.3$ & 5.2 & $0.02-0.1$ & 0.05 & $6.1-7.8$ & 6.8 \\
\hline & Low Land & $5.4-6.1$ & 5.7 & $0.2-0.3$ & 0.23 & $8.0-10.7$ & 9.4 \\
\hline
\end{tabular}

Table.3 Soil fertility status of the study area

\begin{tabular}{|c|c|c|c|c|c|c|c|c|c|c|c|}
\hline \multirow{4}{*}{$\begin{array}{c}\text { Name } \\
\text { of } \\
\text { Village }\end{array}$} & \multirow{4}{*}{ Land Type } & \multicolumn{10}{|c|}{ Available Nutrient Status } \\
\hline & & \multicolumn{2}{|c|}{$\mathrm{N}$} & \multicolumn{2}{|c|}{$\mathrm{P}$} & \multicolumn{2}{|c|}{$\mathrm{K}$} & \multicolumn{2}{|l|}{$\mathrm{S}$} & \multicolumn{2}{|l|}{ B } \\
\hline & & \multicolumn{6}{|c|}{$\left(\mathrm{kg} \mathrm{ha}^{-1}\right)$} & \multicolumn{4}{|c|}{$\left(\mathrm{mg} \mathrm{kg}^{-1}\right)$} \\
\hline & & Range & Mean & Range & Mean & Range & Mean & Range & Mean & Range & Mean \\
\hline \multirow[t]{3}{*}{ Kuaput } & Upland & $50-100$ & 83 & $13-18$ & 16 & $44-64$ & 57 & $2.7-2.9$ & 2.8 & $1.34-1.38$ & 1.36 \\
\hline & Medium Land & $113-125$ & 121 & $20-22$ & 20 & $90-144$ & 116 & $2.9-3.1$ & 3.0 & $1.42-1.53$ & 1.47 \\
\hline & Low Land & $125-188$ & 156 & $22-36$ & 28 & $161-313$ & 208 & $3.6-5.3$ & 4.1 & $1.71-2.31$ & 1.99 \\
\hline \multirow[t]{3}{*}{ Haladia } & Upland & $63-88$ & 71 & $11-12$ & 12 & $188-294$ & 240 & $2.6-3.0$ & 2.9 & $0.91-1.42$ & 1.10 \\
\hline & Medium Land & $11-125$ & 113 & $13-16$ & 15 & $327-347$ & 336 & $3.2-3.4$ & 3.3 & $1.44-1.49$ & 1.47 \\
\hline & Low Land & $125-138$ & 128 & $18-28$ & 22 & $351-458$ & 409 & $3.5-4.8$ & 3.9 & $1.52-1.77$ & 1.63 \\
\hline \multirow[t]{3}{*}{ Kumvadei } & Upland & $50-100$ & 79 & $14-16$ & 15 & $44-83$ & 62 & 3.0 & 3.0 & $1.35-1.4$ & 1.37 \\
\hline & Medium Land & $100-125$ & 113 & $20-24$ & 21 & $86-153$ & 129 & $3.2-3.5$ & 3.4 & $1.5-1.7$ & 1.61 \\
\hline & Low Land & $138-225$ & 184 & $33-52$ & 43 & $140-321$ & 208 & $3.6-11.0$ & 5.8 & $1.75-2.68$ & 2.33 \\
\hline \multirow{3}{*}{$\begin{array}{c}\text { Khatuapa } \\
\text { da }\end{array}$} & Upland & $50-100$ & 75 & $18-30$ & 25 & $38-81$ & 66 & $2.1-2.6$ & 2.4 & $1.30-1.38$ & 1.34 \\
\hline & Medium Land & 113 & 113 & $37-51$ & 45 & $90-130$ & 116 & $2.6-3.3$ & 3.0 & $1.38-1.43$ & 1.41 \\
\hline & Low Land & $125-225$ & 156 & $57-90$ & 73 & $132-394$ & 274 & $3.5-10.4$ & 6.4 & $1.44-1.51$ & 1.47 \\
\hline
\end{tabular}


Table.4 Correlation between different soil properties

\begin{tabular}{|c|c|c|c|c|c|c|c|c|c|c|c|}
\hline & \%Sand & \%Silt & \% Clay & pH & EC & OC & Av N & Av P & Av K & Av S & Av B \\
\hline \%Sand & 1 & & & & & & & & & & \\
\hline \%Silt & $-0.88^{* *}$ & 1 & & & & & & & & & \\
\hline $\begin{array}{c}\text { \% } \\
\text { Clay }\end{array}$ & $-0.98^{* *}$ & $0.80^{* *}$ & 1 & & & & & & & & \\
\hline pH & $-0.92^{* *}$ & $0.76^{* *}$ & 0.93 & 1 & & & & & & & \\
\hline EC & -0.14 & 0.28 & 0.09 & 0.29 & 1 & & & & & & \\
\hline OC & -0.37 & 0.36 & 0.37 & $0.57 *$ & $0.70^{*}$ & 1 & & & & & \\
\hline Av N & -0.11 & 0.14 & 0.10 & 0.38 & $0.76^{* *}$ & $0.76^{* *}$ & 1 & & & & \\
\hline Av P & 0.07 & -0.02 & -0.04 & 0.10 & 0.47 & $0.54^{*}$ & $0.56 *$ & 1 & & & \\
\hline Av K & -0.83 & $0.66 *$ & $0.86^{* *}$ & $0.92 * *$ & 0.39 & $0.65 *$ & 0.47 & 0.33 & 1 & & \\
\hline Av S & -0.11 & 0.14 & 0.11 & 0.31 & $0.71 *$ & $0.61 *$ & $0.76^{* *}$ & $0.79 * *$ & $0.51 *$ & 1 & \\
\hline Av B & 0.07 & 0.01 & -0.02 & 0.22 & $0.74 *$ & $0.58^{*}$ & $0.79 * *$ & 0.17 & 0.26 & $0.52^{*}$ & 1 \\
\hline
\end{tabular}

$(*=5 \%$ level of significance, $* *=1 \%$ level of significance $)$

\section{Available potassium}

Available soil potassium content of Kuaput village were found to vary in between 44 to $313 \mathrm{~kg} \mathrm{ha}^{-1}$ with a mean value of $135.3 \mathrm{~kg}$ $\mathrm{ha}^{-1}$; that of Haladia village varied between 188 to $458 \mathrm{~kg} \mathrm{ha}^{-1}$ with a mean value of 336.5 $\mathrm{kg} \mathrm{ha}{ }^{-1}$; that of Kumvadeivaried widely between 44 to $321 \mathrm{~kg} \mathrm{ha}^{-1}$ with a mean value of $140.4 \mathrm{~kg} \mathrm{ha}^{-1}$; that of Khatuapada village varied between 38 to $394 \mathrm{~kg} \mathrm{ha}^{-1}$ with a mean value of $164.0 \mathrm{~kg} \mathrm{ha}^{-1}$ (Table 3). The results clearly showed a gradual increase in average $\mathrm{K}$ content from upland to low land which could be attributed to the increased clay content in the low land than that of upland and medium land (potassium ion being a cation present in the exchange site of negatively charged clay particles). Available $\mathrm{K}$ was found to be positively correlated with amount of clay content $\left(\mathrm{r}=0.86^{* *}\right)$ (Table 4). In the entire study area available potassium was found within the range of low to high. Similar results were also observed by Mishra et al., (2017) and Dash et al., (2018).

\section{Available sulphur}

Available soil sulphur content of Kuaput village were found to vary in between 2.7 to
$5.3 \mathrm{mg} \mathrm{kg}^{-1}$ with a mean value of $3.5 \mathrm{mg} \mathrm{kg}^{-1}$; that of Haladia village varied between 2.6 to $4.8 \mathrm{mg} \mathrm{kg}^{-1}$ with a mean value of $3.4 \mathrm{mg} \mathrm{kg}^{-1}$; that of Kumvadei varied widely between 3.0 to $11.0 \mathrm{mg} \mathrm{kg}^{-1}$ with a mean value of $4.2 \mathrm{mg}$ $\mathrm{kg}^{-1}$; that of Khatuapada village varied between 2.1 to $10.4 \mathrm{mg} \mathrm{kg}^{-1}$ with a mean value of $4.2 \mathrm{mg} \mathrm{kg}^{-1}$ (Table 3). The results clearly showed a gradual increase in average $\mathrm{S}$ content from upland to low land which could be attributed to the increased SOC content in the low land than that of upland and medium land (as $\mathrm{S}$ is also released from the soil organic matter by the activity of micro-organisms). Available $\mathrm{S}$ was found to be positively correlated with organic carbon $\left(\mathrm{r}=0.61^{*}\right)($ Table 4$)$. In the entire study area available sulphur was found to be in the range of low to medium. Similar results were also observed by Nahak et al., (2016) and Mishra (2016).

\section{Available Boron}

Hot water extractable boron content of the surface soil samples of Kuaput village were found to vary in between 1.34 to $2.31 \mathrm{mg} \mathrm{kg}^{-1}$ with a mean value of $1.65 \mathrm{mg} \mathrm{kg}^{-1}$; that of Haladia village varied between 0.91 to 1.77 
$\mathrm{mg} \mathrm{kg}^{-1}$ with a mean value of $1.42 \mathrm{mg} \mathrm{kg}^{-1}$; that of Kumvadei varied widely between 1.35 to $2.38 \mathrm{mg} \mathrm{kg}^{-1}$ with a mean value of $1.83 \mathrm{mg}$ $\mathrm{kg}^{-1}$; that of Khatuapada village varied between 1.30 to $1.51 \mathrm{mg} \mathrm{kg}{ }^{-1}$ with a mean value of $1.42 \mathrm{mg} \mathrm{kg}^{-1}$ (Table 3). The results clearly showed a gradual increase in average B content from upland to low land which could be attributed to the increased SOC content in the low land than that of upland and medium land. Available B was found to be positively correlated with organic carbon $\left(\mathrm{r}=0.58^{*}\right)$ (Table 4). In the entire study area available boron was found to be in sufficient range. This type of result is in close conformity with results obtained by Pattanayak (2016).

From the above study it was found that the soils were very-slightly acidic (17\%), slightly acidic (13\%), moderately acidic (27\%), strongly acidic (28\%), very strongly acidic (12\%) and extremely acidic (3\%). SOC content of the study area was found to be high $(10 \%)$, medium (67\%) and low range $(23 \%)$. Entire study area was found to be low in available nitrogen content $(100 \%)$. The soil available phosphorus was found to be high $(23 \%)$, medium $(62 \%)$ and low range $(15 \%)$. Available potassium was found to be in low (32\%), medium (38\%) and high range (30\%). Entire study area was found to be low in available sulphur content (100\%). Hence, 25 per cent more fertilizers than that of the recommended dose should be applied in the plots having lower range of nutrients. In case of the plots of the farm having higher status of nutrients, 25 per cent less fertilizers than that of the recommended dose should be applied and recommended dose should be applied. In the rest of the plots having medium range, recommended dose of fertilizers should be applied. Since all the plots of the farm were found to lower in available nitrogen and sulphur status, 25 per cent more sulphur containing fertilizers than that of the recommended dose should be applied. In the entire the study area, micronutrient boron was found to be in sufficient range.

In conclusion, soil acidity was found to be the major crop production constraint in the study area. Soils of the entre study area were found to be deficient in available nitrogen and sulphur content. Deficiency of phosphorus and sulphur were also noticed in many of the plots. Soil erosion and water logging were found to be the major constraints in upland and low land respectively. So, application of liming materials along with application of soil test based fertilizers will help to obtain higher crop production. Application of organic manures along with the inorganic will not only help in enriching the soils with organic matter but also will be a key for sustaining soil health and quality.

\section{References}

Barik, R., Saren, S., Mishra, A. and Acharya, BP. 2017. Soil fertility status of some villages in Astaranga bock of Puri District of East and South Eastern Coastal Plain Agro Climatic Zone of Odisha. Annals of Plant and Soil Research.19 (4):408-412.

Behera, S., Mishra, A., Acharya, BP., Saren, S., and Mishra, J. 2016. Soil fertility status of some villages under East and South Eastern Coastal Plain agro climatic zone of Odisha. Journal of Indian Society of Coastal Agricultural Research. 34(1):63-67.

Bouyoucos, GJ. 1962. Hydrometer method improved for making particle size analysis of soils. Agronomy Journal. 54: 464.

Bray, RH., and Kurtz, Lt.1945. Determination of total, organic and available forms of phosphorus in soils. Soil Science. 59: 39-45. 
Chesnin, L., and Yien, CH. 1950. Turbidimetric determination of available sulphates. Proceedings of Soil Science Society of America. 14:149-51.

Dash, PK., Mishra, A., Saren, S., Revathi, B., and Sethy, SK. 2018. Preparation of GPS and GIS Based Soil Fertility Maps and Identification of Soil Related Crop Production Constraints of RRTTS and KVK Farm, Dhenkanal Located in the Mid-Central Table Land Agro Climatic Zone of Odisha, India. International Journal of Chemical Studies. 6(5): 934-943.

Digal, M.,Saren, S., Mishra, A., Dash, PK., Swain, N., and Acharya, BP. 2018. Soil Fertility Status of Some Villages in Phiringia Block of Kandhamal District under North-Eastern Ghat Agro Climatic Zone of Odisha, India. Journal of Pharmacognosy and Phytochemistry. 7(6):659-662.

Hanway, JJ., and Heidel, H. 1952. Soil analysis methods as used in Iowa State College Soil Testing Laboratory. Iowa State College Bulletin. 57: 1-31.

Jackson, ML.1973. Soil Chemical Analysis. Prentice Hall of India. Private limited, New Delhi.

John, MK., Chuah, HH., and Ndufeld, JH. 1975. Application of improved azomethine-H method to the determination of boron in soils and plants. Analytical Letters. 8: 559-568.

Mishra, A., Das, D., and Saren, S. 2013. Preparation of GPS and GIS Based Soil Fertility maps for Khurda district of Odisha. Indian Agriculturist.57 (1):1 1-20.

Mishra, A., Das, D., Saren, S. and Dey, P. 2017. GPS and GIS based soil fertility maps of Bhadrak District of Odisha. Ecology Environment and Conservation. 23(1): 207-213.
Mishra, A., Das, D., Saren, S., and Dey, P. 2016. GPS \& GIS based soil fertility maps of Nayagarh district Odisha, Annals of plant \& soil research. 18(1):23-28.

Mishra, A., Pattnaik, T., Das, D., and Das, M. 2014. Soil Fertility maps preparation using GPS and GIS in Dhenkanal District, Odisha, India. International Journal of Plant and Soil science. 3(8):986-994.

Mishra, DP. 1981. Morphological Studies and Classification of Soils of Hirakud Command Area. Ph.D. Thesis, Department of Soil Science and Agricultural Chemistry, OUAT, Bhubaneswar.

Nahak, T., Mishra, A., Saren, S., and Pogula, S. 2016. GPS and GIS based soil fertility maps of Ranital KVK farm and identification of soil related production constraints. International Journal of Agricultural Science. 8(51): 2242-2251.

Nanda, SK., Mishra, A., Pradhan, NK., and Muralidharudu, Y. 2008. Soil testing and fertilizer recommendation in Odisha. AICRP on Soil Test Crop Response, Department of Soil Science and Agricultural Chemistry, OUAT, BBSR.

Nayak, SR., Saren, S., Mishra, A., and Acharya, BP. 2014. Soil Fertility Status of Some Villages in Chilika Block of North Eastern Ghat Agroclimatic Zone of Odisha. International Journal of Environmental and Agriculture Research. 1(2):1-5.

Page, AL., Miller, RH., and Keeney, DR. 1982. Methods of Soil Analysis, part-2 (Edn.), Monograph No.9, American Society of Agronomy, Agronomy series ASA SSA. Publishers, Medision, Wisconsin, USA, pp. 621622.

Patil, AH., Kumbhar, AV., and Nale, VN. 
2017. GIS-GPS based soil fertility maps of Agriculture College Farm, Kadegaon District, Maharashtra. International Journal of Engineering Science and Computing.7 (11):1542615430.

Pattanayak, T. 2016. Preparation of GPS based soil fertility maps and identification of soil related crop production constraints for Dhenkanal District, Odisha, Ph.D. Thesis, Department of Chemistry, Institute of Technical Education and Research, Siksha 'O' Anusandhan University, Bhubaneswar.

Priyadarshini, P., Saren, S., Mishra, A., and Acharya, BP. 2017. Soil fertility status of some villages under North-Eastern Coastal Plain Agro climatic Zone of Odisha. Journal of Indian Society of
Coastal Agricultural Research. 35(2): 42-47.

Sahu,GC., and Mishra, A. 2005. Soils of Orissa and their management. Orissa Review, LXII. 4:56-60.

Satpathy, S., Mishra, A., Saren, S., and Acharya, BP. 2015. A study on soil Fertility status of some villages in Nimapara block of East and South Eastern Coastal plain Agroclimatic Zone of Odisha. International Journal of Chemical and Pharmaceutical Review and Research. 1(1), 18-23.

Subbiah, BV., and Asija, GL. 1956. A rapid procedure for the determination of available nitrogen in soils. Current Science. pp 25259-25260.

Walkley, AJ., and Black, IA 1934. Estimation of soil organic carbon by the chromic acid titration method. Soil Science. 37: 29-38.

\section{How to cite this article:}

Nibedita Swain, Antaryami Mishra, Subhashis Saren, Prava Kiran Dash, Manoranjan Digal and Bbhuti Bhusan Mishra. 2019. Soil Fertility Status of Some Villages in Khordha and Bhubaneswar Block of Khordha District under North Eastern GhatAgro Climatic Zone of Odisha, India. Int.J.Curr.Microbiol.App.Sci. 8(01): 415-423. doi: https://doi.org/10.20546/ijcmas.2019.801.043 